Journal of Southeast Asian

\title{
[Special Issue on SEA Demographics] Response - Public Policy/ Political Science
}

Sophal Ear

United States Naval Postgraduate School, sophal@alumni.princeton.edu

Follow this and additional works at: https://docs.lib.purdue.edu/jsaaea

Part of the Political Science Commons, and the Public Affairs, Public Policy and Public Administration Commons

\section{Recommended Citation}

Ear, Sophal (2008) "[Special Issue on SEA Demographics] Response - Public Policy/Political Science," Journal of Southeast Asian American Education and Advancement. Vol. 3 : Iss. 1, Article 14.

DOI: $10.7771 / 2153-8999.1110$

Available at: https://docs.lib.purdue.edu/jsaaea/vol3/iss1/14

This document has been made available through Purdue e-Pubs, a service of the Purdue University Libraries. Please contact epubs@purdue.edu for additional information.

This is an Open Access journal. This means that it uses a funding model that does not charge readers or their institutions for access. Readers may freely read, download, copy, distribute, print, search, or link to the full texts of articles. This journal is covered under the CC BY-NC-ND license. 


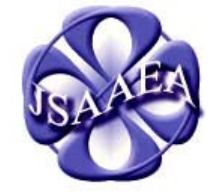

Volume 3
Journal of Southeast Asian American

Education \& Advancement

Www.JSAAEA.org
A peer-reviewed

scholarly journal

published by the

National Association

for the Education \&

Advancement of

Cambodian, Laotian, and Vietnamese Americans (NAFEA)

\title{
Special Issue on Southeast Asian American Demographics
}

\section{Response-Public Policy/Political Science}

\author{
Sophal Ear \\ United States Naval Postgraduate School
}

\section{Introduction}

Mark Pfeifer's (2007) excellent descriptive overview of current demographics of Southeast Asian American populations based on the most recent figures from the U.S. Census and the Current Population Survey offers scholars of social science and public policy a golden opportunity to reflect on the diverse trajectories of the Cambodian, Hmong, Laotian, and Vietnamese communities as they integrate — for lack of a better word —into the salad bowl that is American society.

It seems apparent that out of these four communities, the Vietnamese community is distinct in its higher level of convergence with mainstream American society. This is true across a number of indicators: Income, divorce rate (to be sure, not necessarily a desirable convergence), household and family size, and educational attainment.

From an economics and public policy perspective, educational attainment portends well for the Vietnamese community as education provides skills and knowledge necessary to improve productivity for better paid employment. This largely explains the convergence in income. If nothing else, the credential itself-for example a Bachelor's degree—is a signal of employability, all else being the same.

Household and family size signals reproductive trends that emerge with higher levels of income. As income grows, families choose to have fewer children in a trade-off between quality and quantity. Of course, in traditional societies, children are a form of social protection in the absence of formal social security or retirement systems. The rise of the nuclear family, however, poses new risks for the community. Will grandparents live with their children and grandchildren or will they live alone or in nursing homes? With affluence comes change.

In this short article, I identify through the lens of political science, economics, and public policy some of the challenges facing Southeast Asian American communities as teased from Pfeifer's (2007) overview of the 2005 American Community Survey.

\section{@)}

SOMERIGHISRESERVEDReaders are free to copy, display, and distribute this article, as long as the work is attributed to the author(s) and the Journal of Southeast Asian American Education \& Advancement, it is distributed for noncommercial purposes only, and no alteration or transformation is made in the work. More details of this Creative Commons license are available at http://creativecommons.org/licenses/by-nc-nd/3.0/. All other uses must be approved by the author(s) or JSAAEA. 


\section{Progress Since Initial Resettlement}

My assessment of progress in Southeast Asian American communities since initial refugee resettlement is limited and based only on general historical impressions, since I do not have access to the initial refugee resettlement figures which date back to the 1980s and 1970s. For example, while Cambodian refugees who arrived prior to 1980 could have been Cambodian diplomats, students, or employees of the U.S. Government (Voice of America, the State Department, etc.), the composition of refugees after 1980 would have been much more diverse in origin. Variation in socioeconomic and demographic background in these initially resettled refugees could have been significant. Thus, while the Boat People may have been individuals with significant means (to afford paying their way onto even a rickety boat, Cambodian refugees in the 1980s were likely overwhelmingly of an agrarian background and unlikely to be the bourgeoisie of Cambodia since, after all, the Khmer Rouge targeted that group for elimination. The progress of the Vietnamese American community, as evidenced in the 2005 American Community Survey, has been most impressive, and perhaps may be partly explained by the high level of human capital they brought with them from initial resettlement. Not surprisingly, the remaining Southeast Asian American communities have yet to achieve parity across a number of demographic and socioeconomic indicators with middle America.

\section{Challenges and Implications for the Future}

I have chosen three areas of interest to examine cleavages in the Southeast Asian American communities. These are homeownership rate, disability rate, and youth.

\section{Homeownership Rate}

The large discrepancy between Cambodia/Hmong vs. Vietnamese/Laotians in this area, if it is not a result of statistical error, suggests that Cambodians and Hmong still have very far to go, and need to have specific programs targeted at them to increase the likelihood of realizing the American Dream. Programs like Acorn (www.acorn.org) need to be made aware of this, if they have not already partnered with these communities.

\section{Disability Rate}

While all four Southeast Asian American groups were below the figures for the United States as a whole in terms of disability status (14.9\%) this could reflect the conversion of Aid to Families with Dependent Children and/or General Assistance benefits (both of which are time-limited) into Supplemental Security Income (SSI) for disability, a trend that has taken place in the aftermath of welfare reform; SSI is the new welfare.

\section{Youth}

The Hmong community is the youngest in terms of age with a median of 18.3 years. The largest population increases from 1990 to 2005 were as follows, based on my calculations of the data as reported by Pfeifer: 
24.3\% for Vietnamese

$16.9 \%$ for Cambodians

$5.76 \%$ for Laotian

1.39\% for Hmong

Because of the Hmong community's young age distribution and its large household and family sizes, the Hmong population stands in distinct contrast from the Vietnamese, Cambodian, and Laotian communities. Furthermore, the influx of recently resettled refugees (15,000 in 2004/06) is a daunting challenge facing policymakers in local communities. Seen another way, this is also an opportunity for transformation through renewal. Education, for example, can transform lives at any age, but especially at 18 years of age. Special attention should be made to not lose a generation of Hmong because policymakers were too slow to recognize important demographic patterns when they emerged.

\section{Caveats on the Data Itself: Accuracy, Fairness, and Holes}

Adapting a phrase from Benjamin Disraeli, Mark Twain (1906) once said that "There are three kinds of lies: lies, damned lies, and statistics." While I am neither a novelist nor a statistician and cannot prima facie determine the accuracy and fair representation of Southeast Asian American communities from these statistics-depending on sampling techniques, size of the sample relative to the population (as a rule of thumb, $25 \%$ minimum) — the following caveats did come to mind.

\section{Income}

The income figures could be somewhat misleading, only because the distribution of Vietnamese and Laotians are clustered in California, which has a high cost of living. Indeed, while incomes are on parity or slightly higher than the overall U.S. levels, the largest proportion of Vietnamese live in western states where the cost of living is high. Their purchasing power is likely diminished as a result. For this reason, a dollar in Texas can buy more than in California.

\section{Educational Attainment}

The Vietnamese community has achieved parity with respect to Bachelor's degrees, but I would surmise that compared to the Asian community as a whole, it still lags. This raises an important caveat. Should we be comparing each group's performance relative to the U.S. population in general or to the Asian community in particular? In this respect, the Asian alone or in combination for both sexes who have attained a Bachelor's degree or higher is well above the United States population average of $17.2 \%$ at a whopping $32 \%{ }^{1}$

\section{Conclusion}

While the data collected in the 2005 American Community Survey is useful, I can imagine that additional variables presented in a longitudinal manner would allow for more in-depth comparison, especially in determining progress made within each community. For example, referring to a 1998 study on Cambodian-Americans (United Way of Greater Los Angeles Study), 
historian David Chandler said "The Cambodians are the worst group in every category except arrests ... The worst literacy, the lowest voting record, the lowest income, the highest infant mortality. In arrests they are fourth or fifth up from the bottom” (as quoted in Mydans, 1999). Mydans' New York Times article was subtitled “In the Killing Fields, Even the Future Died” and prompted my own indignant response entitled "Why Cambodia is No Basket Case" (Ear, 1999). What progress has been made to date? There is little indication from the 2005 American Community Survey that such dire predictions can be made. The road ahead will not be easy, but steady progress has been made and more progress will be made as time passes.

I could not agree more with Pfeifer's conclusion that to "provide a fuller picture of contemporary Cambodian, Hmong, Lao and Vietnamese lives in the United States, additional case studies are needed (utilizing both qualitative and quantitative data) of the socioeconomic experiences and continued social adaptation of these four groups at the local level in both urban and rural settings in the different regions of the United States” (p. 17-18).

As a Cambodian-American scholar, my personal reaction to the 2005 American Community Survey is that these figures suggest that while the Vietnamese community has converged to a large extent into middle America, there is a long road ahead still for Cambodians, Laotians, and Hmong. From homeownership to income to educational attainment, these are the key challenges facing these communities.

\section{Endnotes}

1. Data calculated from http://www.census.gov/population/socdemo/education/cps2005/tab01-10.xls

\section{References}

Ear, S. (1999, January 29). Why Cambodia is no basket case. Jinn Magazine, Retrieved June 2, 2008 from http://www.pacificnews.org/jinn/stories/5.02/990129-cambodia.html

Mydans, S. (1999, January 10). The world: The Khmer Rouge legacy; In the Killing Fields, even the future died. The New York Times, section 4, p.1.

Twain, M. (1906). Chapters from my autobiography. North American Review 186. Project Gutenberg. Retrieved May 23, 2007 from www.gutenberg.org/etext/19987

\section{About the Author}

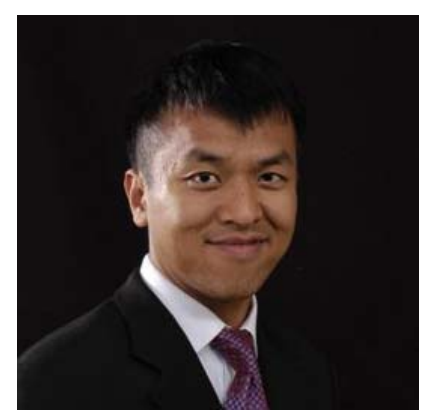

Sophal Ear, Ph.D., is an Assistant Professor of National Security Affairs at the U.S. Naval Postgraduate School in Monterey, California, where he teaches courses on Southeast Asia, stabilization and reconstruction, and research methods. Prior to joining NPS, Dr. Ear was a Post-Doctoral Fellow at the Maxwell School of Syracuse University where he taught policy and administration in developing countries. He has consulted for the World Bank, the Asian Development Bank, and the Food and Agriculture Organization of the UN. Dr. Ear was a USAID grantee for the past decade, and was an Assistant Resident Representative for the United Nations Development Programme Timor-Leste (East Timor) in 2002-2003. A graduate of UC Berkeley and Princeton University, he moved to the United States from France as a Cambodian refugee at the age of ten. 


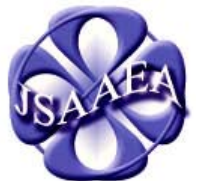

Volume 3

\section{Journal of Southeast Asian American Education \& Advancement} Www.JSAAEA.org
A peer-reviewed scholarly journal published by the National Association for the Education \& Advancement of Cambodian, Laotian, and Vietnamese Americans (NAFEA)

\section{Editor}

Dr. Wayne E. Wright

University of Texas, San Antonio

Associate Editors

Dr. Chhany Sak-Humphry

University of Hawaii

Dr. KimOanh Nguyen-Lam

California State University, Long Beach

Book Review Editor

Dr. Leslie Turpin

School for International Training

Creative Works Editor

Phouang Hamilton

Washington Office of Superintendent of Public Instruction

\section{Special Advisor}

Anne Frank

University of California, Irvine, Southeast Asian Archives

\section{Editorial Assistant \\ Mariana Kuhl}

University of Texas, San Antonio

Comments and questions for the editorial staff may be directed to jsaaea@lists.sis.utsa.edu

\section{Editorial Review Board}

\author{
Dr. Carl L. Bankston III \\ Tulane University \\ Dr. Phala Chea \\ Lowell Public Schools \\ Dr. Changming Duan \\ University of Missouri, Kansas City \\ Dr. Nancy H. Hornberger \\ University of Pennsylvania \\ Dr. Peter Nien-Chu Kiang \\ University of Massachusetts, Boston \\ Dr. Stacey Lee \\ University of Wisconsin, Madison
}

\author{
Dr. Pollie Bith-Melander \\ Asian and Pacific Islander Wellness Center \\ Dr. George Chigas \\ University of Massachusetts, Lowell \\ Dr. Sophal Ear \\ U.S. Naval Post Graduate School \\ Dr. Samlong Inthaly \\ Minneapolis Public Schools \\ Dr. Kevin K. Kumashiro \\ University of Illinois, Chicago \\ Dr. David Chanpannha Ley \\ Montgomery County Public Schools
}


Dr. Sue Needham

California State University, Dominguez Hills

Dr. Max Niedzwiecki

Rights Working Group

Dr. Clara Park

California State University, Northridge

Dr. Loan T. Phan

University of New Hampshire

Dr. Karen Quintiliani

California State University, Long Beach

Dr. Fay Shin

California State University, Long Beach

Dr. Yer J. Thao

Portland State University

Dr. Khatharya Um

University of California, Berkeley

Dr. Terrence G. Wiley

Arizona State University
Dr. Bic Ngo

University of Wisconsin-Madison

Dr. Leakhena Nou

California State University, Long Beach

Dr. Mark Pfeifer

Texas A\&M University, Corpus Christi

Dr. Bounlieng Phommasouvanh

Minnesota Department of Education

Dr. Kalyani Rai

University of Wisconsin, Milwaukee

Dr. Nancy J. Smith-Hefner

Boston University

Dr. Myluong Tran

San Diego State University

Dr. Linda Trinh Vo

University of California, Irvine

Dr. Zha Blong Xiong

University of Minnesota

Dr. Kou Yang

California State University, Stanislaus

\section{Doctoral Student Editorial Review Board}

\author{
Keo Chea \\ University of Pennsylvania \\ Loan Dao \\ University of California, Berkeley \\ Ha Lam \\ Arizona State University \\ Vanna Som \\ Harvard University \\ Giang Pham \\ University of Minnesota \\ Tinou Tran \\ University of Houston, Texas \\ Phitsamay Sychitkokhong Uy \\ Harvard University
}

Vichet Chhuon

University of California, Santa Barbara

Annie BichLoan Duong

San Joaquin County Office of Education

Ravy Lao

University of California, Santa Barbara

Rassamichanh Souryasack

University of California, Santa Barbara

Layheng Ting

State University of New York, Albany

Loan Tran

University of California, Santa Barbara

Yang Sao Xiong

University of California, Los Angeles 